有機金属気相成長法InSb薄膜の 電気的特性に与えるバッファ層の影響*

本間 秀幸*1・石井 辰弥*1・山口 栄雄*1

\title{
The Effect of a Buffer Layer on the Electric Properties of InSb Thin Films Grown by Metalorganic Vapor Phase Epitaxy
}

Hideyuki HOMMA*1, Tatsuya ISHII*1 and Shigeo YAMAGUCHI*1

*1Department of Electrical, Electronic and Information Engineering, Kanagawa University, 3-27-1, Rokkakubashi, Kanagawa-ku, Yokohama, 221-8686, Japan

(Received November 5, 2010, Accepted January 28, 2011)

\begin{abstract}
We have studied the thermoelectric properties of InSb thin films. They were prepared by metalorganic vapor phase epitaxy on sapphire substrate using sputtered InAs buffer layer. Substrate temperature during the deposition of InAs buffer layer was changed between $65^{\circ} \mathrm{C}$ and $250^{\circ} \mathrm{C}$. Electrical properties, thermoelectric properties, and crystalline properties of InSb thin films with a InAs buffer were assessed using Hall measurement, Power factor and X-ray diffraction. The power factor of InSb was as high as $2.1 \times 10^{-4} \mathrm{~W} /$ $\mathrm{mK}^{2}$ at a deposition temperature of $150^{\circ} \mathrm{C}$ of InAs.
\end{abstract}

\section{1. はじめに}

$\mathrm{InSb}$ の特徵は, 高電子移動度と狭いバンドギャップが挙 げられる.これらの特徵から現在赤外検出器やホールセンサ として用いられており1), また今後高電子移動度トランジス タや, 我々が提案してきた熱電变換素子としても期待できる 材料である. 熱電材料としての InSb は, 高電子移動度か ら, 移動度と格子熱伝導率の比の值が比較的高く, 高い熱電 変換効率が期待できる ${ }^{2,3)}$. 本研究では有機金属気相成長法 (MOVPE) により InSb 薄膜の成長を行なった. 基板とし て, サファイア C 面基板 $\left(\mathrm{Al}_{2} \mathrm{O}_{3}(0001)\right)$ を用いた。単結晶 サファイアは六方晶で表すと, 格子定数が, $\mathrm{a}=4.758 \AA$ で あり，そして InSb は (111) 面に垂直方向で成長させる場合 には， $\mathrm{a}=4.581 \AA$ と見積もられることから，ミスフィット が3.7\% と計算され，一般的に $\mathrm{InSb}$ の成長用基板として用い られる GaAs 基板と比べ，ミスフィットが小さくでき，良質 な薄膜が作製できると考えられる.さらにバッファ層の導入 を検討し, 高周波スパッタ法により InAs 層を成長させ，そ の上に InSb を成長させた.このバッファ層の成長時の基板 温度による $\mathrm{InSb}$ 薄膜の結晶性と電気的特性および熱電特性 について報告する。

\section{2. 実験方法}

サファイア $\mathrm{C}$ 面 $\left(\mathrm{Al}_{2} \mathrm{O}_{3}(0001)\right)$ 基板上に高周波スパッタ 法により InAs 層を成膜し, その上に有機金属気相成長法 (MOVPE) により，InSb 層を成長させた，InAs 層の成膜 条件は, ターゲットには単結晶 InAs と金属 Inを用い, 雾 囲気ガスには $\mathrm{Ar}$ を用い, 膜厚は $0.2 \mu \mathrm{m}$ で基板温度を 65 , $100,150,200,250^{\circ} \mathrm{C}$ で行なった. InSb 層の成長条件は, 膜 厚は $1.0 \mu \mathrm{m}$ で成長温度が $490^{\circ} \mathrm{C}$ で行なった．なおサファイア $\mathrm{C}$ 面基板上に直接 $\mathrm{InSb}$ を成長させた場合, 上記の条件を含 む様々な条件により, 成長を試みたが成長しなかった。これ

* 平成 22 年 11 月 4 日 第 51 回真空に関する連合講演会で発表

*1 神奈川大学大学院工学研究科 (下221-8686 神奈川県横浜市神 奈川区六角橋 3-27-1)
はサファイアに対する InSb の濡れ性が悪いためと考えられ る.

作製した InSb 薄膜を, van der Pauw 法によるホール効 果測定により, 電気的特性を測定し, 熱電特性の評価は, パ ワーファクター $P_{\mathrm{f}} に よ り$ 行なった. パワーファクターは次 式で算出される.

$$
P_{\mathrm{f}}=\frac{a^{2}}{\rho}
$$

ここで， $\alpha$ はゼーベック係数， $\rho$ は抵抗率である. ゼーベッ ク係数を測定し, van der Pauw 法により, 抵抗率を測定 し，パワーファクターにより評価を行なった． また結晶性評 価を $\mathrm{X}$ 線回折により行なった。 サファイア C 面基板には $\operatorname{InSb}(111)$ が成長することが確認できたので， $2 \theta$ とロッキ ングカーブでの InSb(111)のピークの半值幅 (FWHM) に より結晶性を評価した。 また InSbの残留応力を計算した。 応力計算には, 基板からの二軸性応力が InSb に働くものと し, 弾性定数は $\operatorname{InSb}(001)$ につてのパラメータ值から, 座 標変換を行い, $\operatorname{InSb}(111)$ の弾性定数とした. $\operatorname{InSb}(001)$ の 弾性定数は $\mathrm{C}_{11}=66.7, \mathrm{C}_{12}=36.5, \mathrm{C}_{44}=30.2 \mathrm{GPa}$ であること より ${ }^{4)}$, 応力 $\sigma$ と歪み $\varepsilon$ は次のように表される 次, $^{5,}$.

$$
\begin{aligned}
& \left(\begin{array}{l}
\sigma_{11} \\
\sigma_{22} \\
\sigma_{33} \\
\sigma_{23} \\
\sigma_{13} \\
\sigma_{12}
\end{array}\right)=\left(\begin{array}{cccccc}
81.8 & 32.5 & 26.4 & 0 & 7.1 & 0 \\
31.5 & 81.8 & 26.4 & 0 & -7.1 & 0 \\
26.4 & 26.4 & 86.8 & 0 & 0 & 0 \\
0 & 0 & 0 & 20.1 & 0 & -7.1 \\
7.1 & -7.1 & 0 & 0 & 20.1 & 0 \\
0 & 0 & 0 & -7.1 & 0 & 25.2
\end{array}\right)\left(\begin{array}{c}
\varepsilon_{11} \\
\varepsilon_{22} \\
\varepsilon_{33} \\
\varepsilon_{23} \\
\varepsilon_{13} \\
\varepsilon_{12}
\end{array}\right) \\
& \varepsilon_{11}=\frac{a-a_{0}}{a_{0}}, \quad \varepsilon_{33}=\frac{c-c_{0}}{c_{0}}, \quad \varepsilon_{11}=\varepsilon_{12}
\end{aligned}
$$

ここで $c$ の方向が $\operatorname{InSb}(111)$ である. InAs バッファ層の組 成比をエネルギー分散型蛍光 X 線分析装置 (EDX) により 見積もり, InSb 薄膜の表面観察を走査型電子顕微鏡 $(\mathrm{SEM})$ により行なった。 


\section{3. 実 験 結 果}

van der Pauw 法による測定した電子移動度を Fig. 1 に， キャリア濃度をFig. 2 に示す。これらの結果により，すべ ての試料でキャリアが電子であることが分かったＩnAsの 基板温度が $100^{\circ} \mathrm{C}$ のと，最も高い電子移動度となり，626 $\mathrm{cm}^{2} / \mathrm{Vs}$ を示した。キャリア濃度は $150^{\circ} \mathrm{C} て ゙$ 最大となり, $5.62 \times 10^{18} \mathrm{~cm}^{-3}$ であった.

パワーファクターによる熱電特性を Fig. 3 に示す. $150^{\circ} \mathrm{C}$

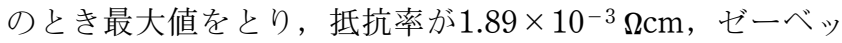
ク係数が $-6.3 \mu \mathrm{V} / \mathrm{K}$ により $2.1 \times 10^{-4} \mathrm{~W} / \mathrm{mK}^{2}$ となった。な お一般的にキャリア濃度が大きくなると，ゼーベック係数は 小さくなる. 今回の試料ではキャリア濃度が大きいとパワー ファクターも大きくなり，基板温度に対して傾向も同じよう になった。これはゼーベック係数が全体的に低くかったた め，キャリア依存性が小さかったと考えられる，また実用に はパワーファクターは $10^{-3} \mathrm{~W} / \mathrm{mK}^{2}$ オーダー必要といわれ ている. 電子移動度とともに特性が覀かったため, 更なる膜 質の改善の必要性がある.

$\mathrm{X}$ 線回折による InSbの結晶性を Fig. 4 に示す。 $2 \theta$ とロ

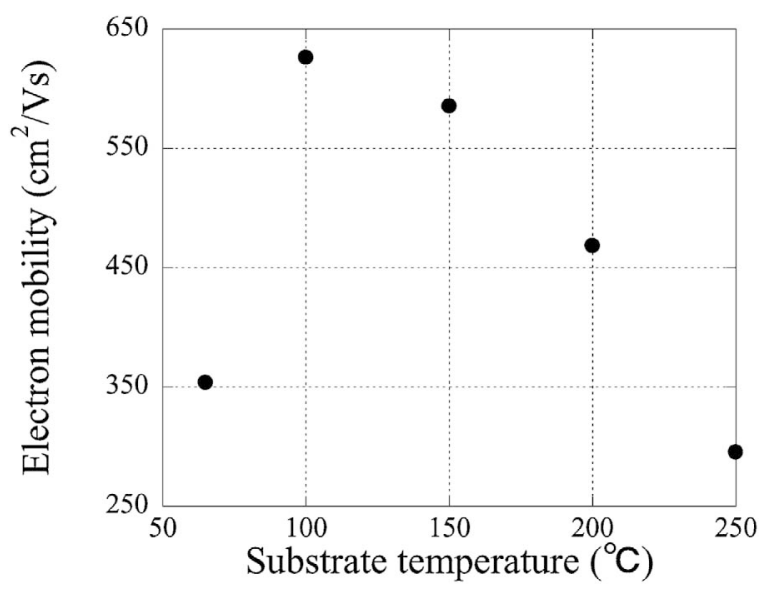

Fig. 1 Substrate temperature dependence of electron mobility of InSb.

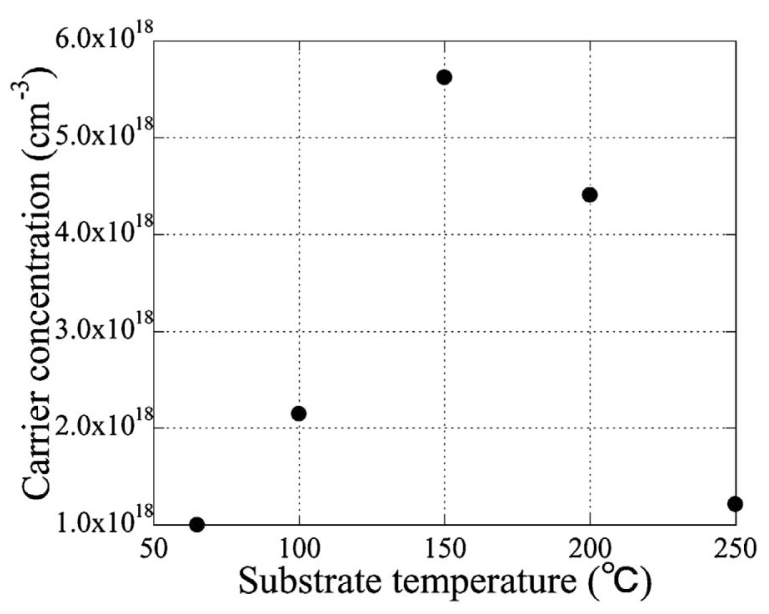

Fig. 2 Substrate temperature dependence of carrier concentration of InSb.
ッキングカーブの半值幅は同じ傾向であり, InAs の基板温 度が高くなると半值幅が狭くなり, 結晶性が向上している. $250^{\circ} \mathrm{C}$ での $2 \theta$ とロッキングカーブの半值幅はそれぞれ 72.7 と

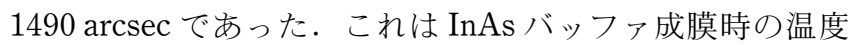
が高いと膜質が良くなり，この上に成長する InSbの結晶状 態も向上したと考えられる. また InSbの残留応力を Fig. 5 を示す. InAs の基板温度が $65^{\circ} \mathrm{C}$ のみ引っ張り応力で, 他の 温度では圧縮応力であることが分かった.

EDX による InAs バッファ層の組成比を Fig. 6 を示す. InAs の基板温度を $65^{\circ} \mathrm{C}$ から $150^{\circ} \mathrm{C}$ と温度を上げると As と In の比が 0.51 と 1 に近づくが， $200^{\circ} \mathrm{Cを}$ 超えて組成比が小さく なった.これは基板温度の上昇より表面拡散により As が取 り込まれ易くなると考えられるが，200ㄷあたりから，As の蒸発が大きくなるためと考えられる. パワーファクターは $150^{\circ} \mathrm{C}$ が最大をとり, 電子移動度も $585 \mathrm{~cm}^{2} / \mathrm{Vs}$ と比べて高 い方であったため, バッファ層の As と In は高い As/In 比 が良いことが考えられる．またターゲットが InAs + In であ るため, 組成比が 1 以下であることは InAs と Inの 2 成分 存在することが考えられる. ターゲットのInの面積を減ら すなどで，組成比を高くするにする必要性が示唆される.

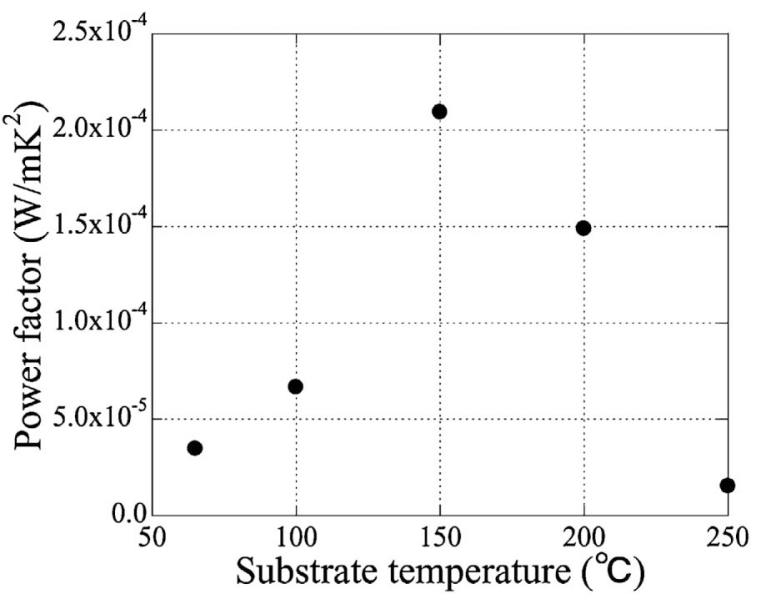

Fig. 3 Substrate temperature dependence of power factor of InSb.

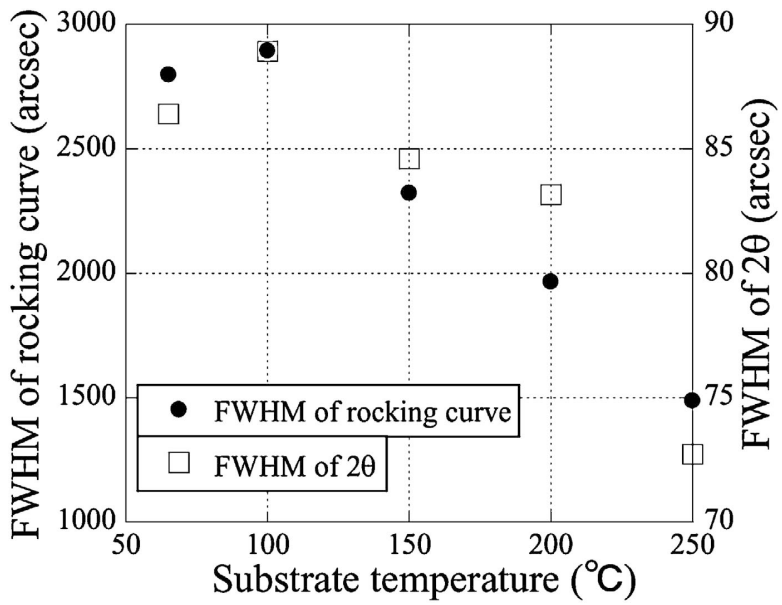

Fig. 4 Substrate temperature dependence of FWHMs of $2 \theta$ and rocking curve for InSb (111). 


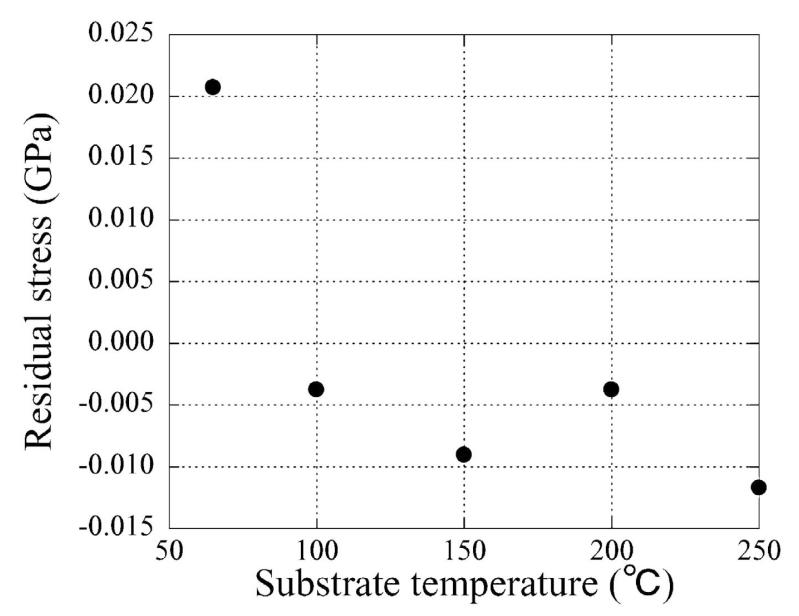

Fig. 5 Substrate temperature dependence of residual stress of InSb.

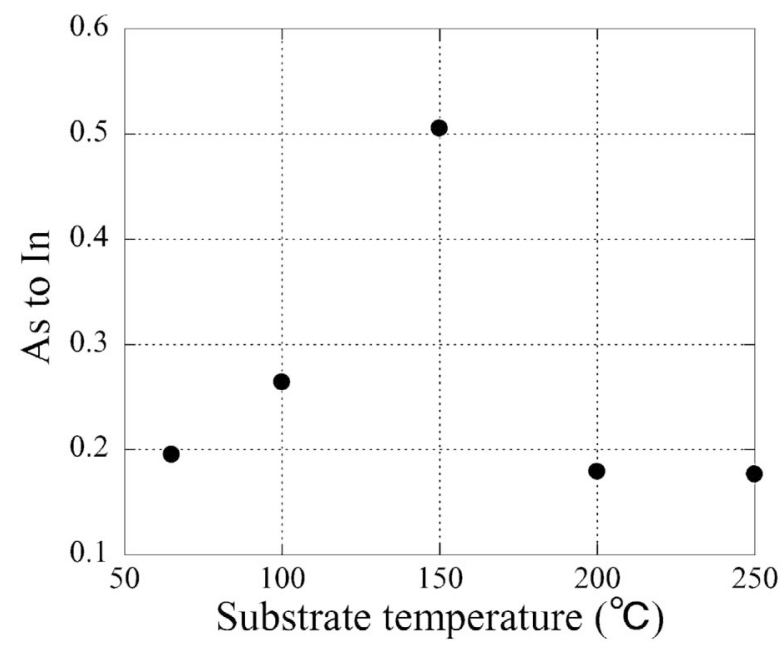

Fig. 6 Substrate temperature dependence of composition ratio of As to In.

$\mathrm{InSb}$ の結晶性では InAs の基板温度は $250^{\circ} \mathrm{C}$ が良いが，結晶 性の良い領域が電気的特性に表れるほど, 膜の全体に存在し ない可能性が考えられる.

InAs の基板温度が $65^{\circ} \mathrm{C}$ と $250^{\circ} \mathrm{C}$ バッファ層を用いた InSb 薄膜のSEM による表面画像を Fig. 7 に示す. $65^{\circ} \mathrm{C}$ の試料 の方が，穴が多く密度が低いように思われる。これはX線 回折による応力から Fig. 7(a)の方は引っ張り応力であり,

Fig. 7(b) は圧縮応力であったため, 受けている残留応力が 膜の形状に影響を与えたと考えられる。

\section{4. まとめ}

サファイア C 面基板上に基板温度を変化させた InAs バッ ファ層を用いて InSb を成長させた。 バッファ層がないとき と比べ, 薄膜として成長させることができ, X線回折の口 ッキングカーブ測定から $\operatorname{InSb}(111)$ が配向していることが確
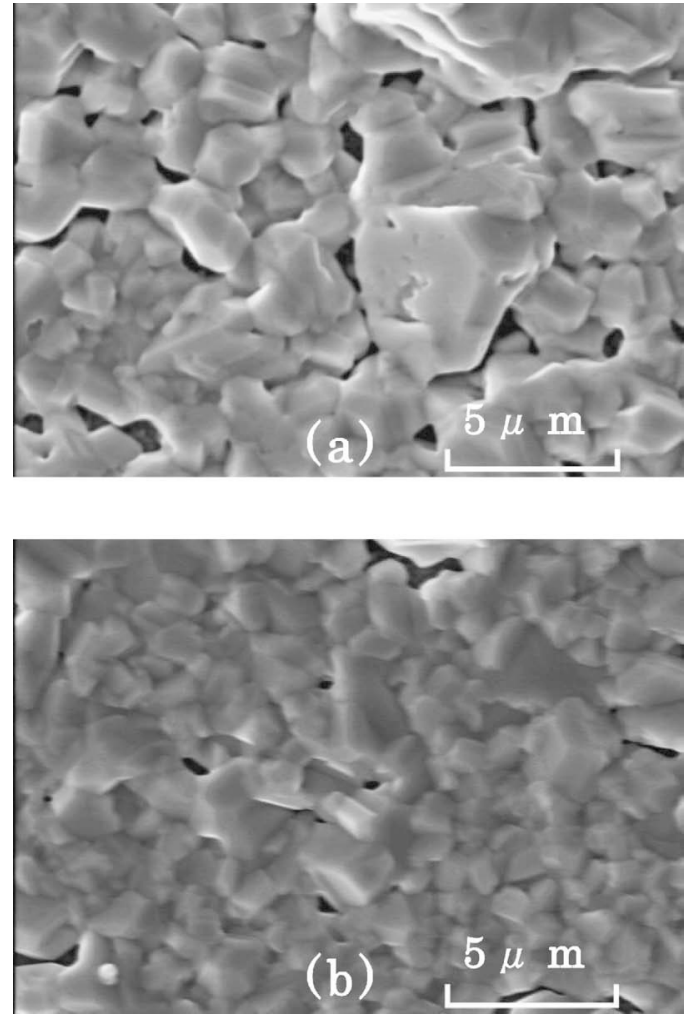

Fig. 7 SEM images of InSb surface: (a) at a substrate temperature of $65^{\circ} \mathrm{C}$, (b) at a substrate temperature of $250^{\circ} \mathrm{C}$.

認できた，基板温度が $100^{\circ} \mathrm{C}$ とき，電子移動度が $626 \mathrm{~cm}^{2} /$ Vs となり, $150^{\circ} \mathrm{C}$ とき, キャリア濃度, パワーファクター が最大をとりそれぞれ $5.62 \times 10^{18} \mathrm{~cm}^{-3}, 2.1 \times 10^{-4} \mathrm{~W} / \mathrm{mK}^{2}$ となった。 また $150^{\circ} \mathrm{C} て ゙$ 電子移動度 $585 \mathrm{~cm}^{2} / \mathrm{Vs}$ と $100^{\circ} \mathrm{C}$ と比 べ大きく減.しているわけではなく, 電気的特性抢よび熱電 特性は基板温度 $150^{\circ} \mathrm{C}$ が良い值となった。この温度に扔いて InAs バッファ層の組成比は 0.51 と他の温度比べて高い結果 となった。このことからバッファ層としてInAs を用いる場 合高いAs/In 比率がよいことが考えられる.

\section{〔文献〕}

1) Infrared Technology, Applications to Electro-optics, Photonic Devices, and Sensors, ed. by A. R. Jha (John Wiley \& Sons, Inc., New York, 2000).

2) S. Yamaguchi, Y. Nagawa, N. Kaiwa and A. Yamamoto: Appl. Phys. Lett. 86 (2005) 153504.

3) S. Yamaguchi, T. Matsumoto, J. Yamazaki, N. Kaiwa and A. Yamamoto: Appl. Phys. Lett. 87 (2005) 201902.

4) Handbook Series on Semiconductor Parameters vol. 1, ed. by M. Levinshtein, S. Rumyantsev and M. Shur (World Scientific, Singapore, 1999), p. 210.

5) THEORY OF DISLOCATIONS, ed. by J. P. Hirth and J. Lothe (Kriger Publishing Company, Florida, 1982), p. 431.

6) S. Yamaguchi and M. Matsumoto: Vacuum 84 (2010) 1323. 